IRA-International Journal of Management \&

Social Sciences

ISSN 2455-2267; Vol.09, Issue 01 (October 2017)

Pg. no. 14-26

Institute of Research Advances

http://research-advances.org/index.php/RAJMSS

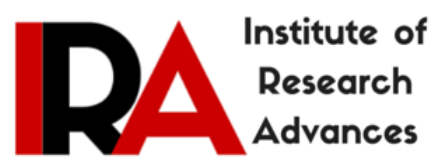

\title{
Unearthing the Double Bottom Line Commitments of Indian Microfinance Institutions
}

\author{
Prasenjit Roy \\ Ph.D. Research Scholar \\ Dept. of Commerce, North Eastern Hill University, Shillong-793022, Meghalaya, India.
}

Type of Review: Peer Reviewed.

DOI: http://dx.doi.org/10.21013/jmss.v9.v1.p3

How to cite this paper:

Roy, P. (2017). Unearthing the Double Bottom Line Commitments of Indian Microfinance Institutions. IRA-International Journal of Management \& Social Sciences (ISSN 2455-2267), 9(1), 14-26. doi:http://dx.doi.org/10.21013/jmss.v9.n1.p3

(C) Institute of Research Advances.

\section{(cc) BY-NO}

This work is licensed under a Creative Commons Attribution-Non Commercial 4.0 International License subject to proper citation to the publication source of the work.

Disclaimer: The scholarly papers as reviewed and published by the Institute of Research Advances (IRA) are the views and opinions of their respective authors and are not the views or opinions of the IRA. The IRA disclaims of any harm or loss caused due to the published content to any party.

Institute of Research Advances is an institutional publisher member of Publishers Inter Linking Association Inc. (PILA-CrossRef), USA. The institute is an institutional signatory to the Budapest Open Access Initiative, Hungary advocating the open access of scientific and scholarly knowledge. The Institute is a registered content provider under Open Access Initiative Protocol for Metadata Harvesting (OAI-PMH).

The journal is indexed \& included in WorldCat Discovery Service (USA), CrossRef Metadata Search (USA), WorldCat (USA), OCLC (USA), Open J-Gate (India), EZB (Germany) Scilit (Switzerland), Airiti (China), Bielefeld Academic Search Engine (BASE) of Bielefeld University, Germany, PKP Index of Simon Fraser University, Canada. 


\begin{abstract}
The microfinance industry has emerged from a small domain institution to a broad tool for social development, as many success stories reveal its true potential for serving the society. Nonetheless, like every institution, it has to be sustainable in carrying out its developmental activities. This is where the idea of double bottom line surfaces where a win-win situation is attained for the microfinance institutions along with the clients to whom they are serving. Although there are other unprincipled grounds associated with the concept which obstruct this thought and deviates the MFI activities in accomplishing better and higher revenues. This leads to a trade-off. The paper tries to explore the presence the double bottom line in the MFIs of India. Further, to find if there is a trade-off between financial performance and social performance. A dataset comprising all the Indian MFIs reported in www.mixmarket.org for the period from 2009 to 2013 has been used for the study. The analysis is carried on various indicators that resemble the performance and efficiency of the MFIs. The evidence suggests a moderate trade-off in the operations of the Indian MFIs although largely they adhere to the double bottom line. They are mainly guided by outreach scale in terms of a number of borrowers.
\end{abstract}

JEL Classification: C33, G21, G28, G32

Keywords:Microfinance, double bottom line, trade-off, financial performance, and social performance.

\title{
Introduction:
}

The complexity of the business transaction led to the creation of financial systems in order to simplify and channelize the financial industry. Financial institutions were set up revolutionizing the aspects of modern industrial society by rendering services of utmost nature that forever changed the World. However, as these changes occurred one part of the society was always deprived of attaining these services let alone enjoys these changes i.e. the poor. The formal banking system never really showed any interest in giving its support to the poor on the premise that they are unworthy and non-bankable. This created a financially exclusive society. This exclusion further jeopardized the societal norms where they also suffered from social exclusion. This is where microfinance offered its valuable services to the poor for bringing a change and building a better future. These services included various activities that ranged from micro saving, micro credit, micro insurance, money transfer etc. The vision was centered for a better future through economic upliftment. Until recently microfinance has been regarded as an important tool for poverty alleviation and economic empowerment. Ever since its modern inception in Bangladesh, it has generated many successful stories of empowerment within the poorest sections of the society across the world. The United Nations declared the year 2005 as the "International Year of Microcredit" and in the following year, Muhammad Yunus and Grameen Bank were awarded Nobel Peace Prize for the initiative through microfinance. As a conventional approach to serving the poor, microfinance institutions (MFIs) have always been established with a common mission statement of eradicating poverty and creating empowered lives. They lend small sums of money to the poor and unlike usual lending institutions without any collateral for a nominal interest.

Nevertheless, in order to survive in the long run, an organization needs to be financially sustainable. Thus the concept of double bottom line emerges where both social performance and financial performance are considered to go hand in hand. However, an imbalance among the two, more prominently wheeling towards the former leads to undesired practices. This is where the idea of a trade-off between financial and social performance is said to transpire in the activities of MFIs. There are many speculations about the various practices of MFIs where they are believed to abandon their social objectives in order to attain financial sustainability for generating additional investments and subsidies (Cull et. al, 2007; Ghosh and Van Tassel, 2008). This further leads to abandoning their intrinsic services and adhere to other activities that bring out the profit orientation in them. However, on a different note, it has also been said that MFIs that are more financially sustainable are effective in terms of outreach in comparison to those which are not (Morduch, 2000). Thus the argument remains whether strong profit orientation is able to address the needs of the poor or vice versa (Roberts, 2013). There are again views that speculate on the intent of the investors and donors having influence over the operations of the MFIs. The investors with a desire for profitability are said to divert the operations of the MFIs towards attaining more returns. These investors are of institutionalist nature. On the other hand, the investors 
that go by the fundamental nature of the MFIs and sacrifice their financial nature for the betterment of the poor are said to be of welfarist nature.

Till 2012 as per MIX market database (www.mixmarket.org) ${ }^{1}$, there were 851 MFIs out of 1288 MFIs (60\%) which were operating under non-NGOs status with over US\$ 91 billion gross loan portfolio showing the emergence of commercialization in the sector and the influence of investors in the operations of the MFIs. More particularly the trend in the evolution of the MFIs is that they are initially established within the genre of NGO (non-governmental organization) status but gradually after attaining maturity they shift gears to NBFC (nonbanking financial corporation) status which further allegedly pollutes their primary concern for poor. For instance, a Bolivian based NGO-MFI named PRODEM came into the limelight with various operational issues related to its transformation into shareholder-owned institution BancoSol (Rhyne, 1998). Bank Rakyat Indonesia also went into initial public offering (IPO) in 2003, which led its operations into charging high interests. The reason primarily associated to it was claimed to be investor preferences driven by profit (Rosengard, 2004). In 2007 Banco Comparatamos an NGO-MFI from Mexico also transformed itself to shareholder enterprise and in a similar approach were alleged of charging high interests. In India too SKS did the same when they went into IPO. Further, the microfinance crisis emerged in Andhra Pradesh in 2010 which highlighted the unethical actions associated with it. Many clients were reported to have committed suicide due to forceful and dissipated tactics for loan repayments. So, the whole idea of trade-off remains open with notions pondering as to whether MFIs should sacrifice financial returns or should they go for it. However, there is another option of a gray line between the two that optimizes a win-win situation for the MFIs as well as the clients. Though there is division among various academicians and practitioners regarding the trade-off theory the most favorable idea is to have an element of both in the form of adouble bottom line. The attempt here is to explore the presence and the extent to which the double bottom line of achieving both financial sustainability and social performance exists among the MFIs of India. Further, as a corollary to this, an attempt has been made to identify the indicators that explain the double bottom line representing indicators of the MFIs.

\section{Section II}

\section{Double bottom line: Evidence from world literature}

Microfinance as a practice originated way back in the $18^{\text {th }}$ century with the Irish Loan Fund that prevailed in funding the poor for developmental purposes (Hollis and Sweetman, 1996). However, with time, it has evolved into a wide structure of various activities where several players emerged bringing change to the values and customs associated with the industry beforehand. As acclaimed globally the modern day microfinance cemented its base in Bangladesh upon the efforts of Mohammed Yunus and Grameen Bank in the 1970s when poverty prevailed predominantly in the country. Microfinance services are established with a singular objective to rule out poverty and bring sustainable social as well as economic development. Upon its success, the concept expanded globally that has been helping millions of lives till this day. However, the MFIs are also required to be financially self-sufficient in order to attract investments and donations which further led to the concept of adouble bottom line. This created an opportunity for the MFIs to go for a win-win situation aiding the clients as well themselves. The thought augmented to such a phase where the prospect to reap profits was visualized and realized compromising the poverty alleviation objective. The concept of providing microfinance services to the poor as well as building up a financially sustainable institution has an expensive feature connected to it where both cost and risk are equally involved. Unlike any other financial institutions engaged in lending activities (Adams and Von Pischke, 1992). Moreover, handling high operational costs of large scale small lending as well managing the risk stemming from non-collateral lending has always been challenging for MFIs, and achieving a fine balance between outreach and financial sustainability has its own challenge where sometimes a disparity occurs in maintaining both (Rhyne, 1998).

The idea of trade-off began in the last decade or so when higher financial sustainability in the MFIs led to abandon the poorest segment from its service zone, instead moderate poor were served to get abetter return (Woller, Dunford and Woodworth, 1999; Christen and Drake, 2001). It is also believed that competition also had its contributions in leading the MFIs towards the trade-off where services were modified towards good returns against the competitors (MacIntosh, De Janvry and Sadoulet, 2005). Coleman (2008) observes that in recent years, the industry has emerged as a platform with various players where some are willing to invest in the sector seeking either profit for themselves or welfare of the poor which often led the MFIs to change its outlook from non-profit to for-profit keeping investor preferences. This domination of financial performance over social performance also led to other adverse activities that are not common in MFIs (Kai, 2009). Bédécarrats, Baur and Lapenu (2012) states that the intention behind better financial performance can only be linked to gather out more funds in the form of subsidy and investment. This certainly has ignorance towards the social aspect of 
investment in the MFIs, however, consideration of both financial and social performance is not an enormous task.

Only a few rigorous attempts have been made up so far to address the topic, but only to end up with uncertain results. A number of studies indicate that the focus on financial performance impulse the MFIs to opt for moderate poor and better-off clients which further increases their profit orientation leading to the trade-off (Olivaries-Polanco, 2005; Ghosh and Van Tassel, 2008; Barzelay, 2008; Ashta and Hudon, 2009). Hermes and Lensink (2007) observes that individual lending methodology are more prevalent as they have been regarded to perform better in terms of profitability in comparison to group-based lending where less poor are being targeted indicating a possible trade-off. Cull, Demirgüç-Kunt and Morduch (2007) establish the same observations in their paper. In assessing the status of MFIs across India it was seen that financial performance was given more weight which further resulted in questionable practices signaling trade-off (Augsburg and Fouillet, 2010). In studying 201 MFIs it was revealed that financial sustainability was targeted through credit risk management where services were provided to selective clientele base through charging high interest (Ayayi and Sene, 2010). In terms of gender preferences, it was also seen that the women borrowers were given less importance indicating a drift from their social objective since women borrowers are regarded as one of the prominent goals of MFIs for empowerment through their services. Similar findings also emerged in India (Sriram, 2010).Hermes, Lensink and Meesters (2011) report on 435 MFIs shows that focus on efficiency i.e. financial sustainability compels the MFIs to lose focus from the poor and drifting away from its mission that leads to trade-off. Copestake (2007) also confirms evidence to atrade-off between outreach and financial performance however he could not establish whether it was a deliberate move or by accident. Frank, Lynch and Schneider-Moretto (2008) conducted a study under Women's World Banking where the find the effect of legal status to influence the MFIs operations. The NGO MFIs were reported to have better outreach than non-NGOMFIs. However, the financial performance was better for the non-NGO MFIs. In a study across Russia, the Caucasus, and Central Asia it was seen that MFIs were inclined more towards profit driven operations were charging high interest were prevalent (Sheremenko, Escalante and Florkowski, 2012). Shylendra (2006) observed that the microfinance crisis in Andhra Pradesh emerged with the advent of high interest rates and rigid repayment policies that led the clients to go for multiple lending. Nair (2010) also points out in Indian context that the transformation of the MFIs from NGO to regulated for-profit enterprises in recent years saw a rising class of profit-driven investors. This further led the MFIs to over-lending and marginalization of the borrowers. Wagenaar (2012) while studying the effect of transformation in MFIs also found that the non-profit organizations which later transformed into for-profit organizations had significantly lower outreach in comparison to what they had before the transformation, indicating trade-off. Salim (2012) studies the same effect in Bangladesh where he finds that for-profit MFIs were more inclined towards revenue generation whereas non-profit NGOs were more competent in outreach and lined up their services more proficiently for poverty eradication. Serrano-Cinca and Gutiérrez-Nieto (2013) analyze 1000 MFIs where they indicate that there is indeed evidence of trade-off, however, similar to Copestake (2007) they could not establish a solid background to it. A recent paper indicates that microfinance is South Asia has undeniably undergone significant changes in operations since its inception. A lot of activity undertaken recently suggests a hint of trade-off in the MFIs with major elements of corporate culture and competition influencing them to achieve better financial returns (Hulme and Maitrot, 2014).

The above literaturebacks up the concept of trade-off to a large extent nonetheless there is additional literature that provides conflicting justification to it leading to an ambiguous idea. For instance, Christen (2001) does observe a commercialization wave across the MFIs in Latin America, however, he says it to be an effect of the business environment factors that are prevalent in the market rather than an intentional move which further boosts up the outreach factors in the industry. A study on 200 MFIs indicates that there is no difference in social orientation and outreach further there was no element of trade-off in the operations of the MFIs (Mersland and Strøm, 2007). Mersland and Strøm (2010) conducted another study on 379 MFIs where they got the same results but quoting different reasons where they suggested that profit-oriented approach is always offset by the unique nature of costs from small loans in MFIs. Roberts (2013) also suggested the same in studying 358 MFIs with reference to higher interest rates. In another study on 702 MFIs it was reported that a minimal amount trade-off in MFIs does exist with less disclosure and transparency, however, there was no solid evidence of trade-off (Quayes, 2012). In terms of breadth of operational sustainability in the Indian sector, Zerai and Rani (2011) finds a moderate trade-off, however, concluded with no real signs of it. Unlike the other studies, Mosley and Hulme (1998) suggested that MFIs which are more financially sustainable delivers good impact to poverty reduction than the ones which are not. Moreover, it can be often seen that the financial sustainability of MFIs is misinterpreted as profit maximization, without considering the budget constraint associated with them (Morduch, 2000).In terms of legal, profit status and performance there was no evidence of trade-off rather the for-profit non-NGO sector MFIs were more efficient than their counterpart (Woller, 2007; TchakouteTchuigoua, 2010). In a study of MENA (Middle Eastern and North Africa) region, Bassem (2012) finds a 
possible indication of trade-off, however, he also concludes on a note that they also have the element of achieving the double bottom line. Louis, Seret and Baesens (2013) also established a positive relationship between financial sustainability and outreach although they could not determine the trade-off. A recent study carried out on 409 MFIs across 71 countries indicates no trade-off between the social objective and financial performance (Kar, 2013). On the whole, the findings from the above put us in a piquant situation. Nonconsistent findings across the studies confound the observation on double bottom line commitments of MFIs in the world literature.

\section{Data and methodological approach}

The datahasbeen takenfrom www.mixmarket.org. The dataset consists of all the Indian MFIs reported in the website (around 100 MFIs) over a period of five years i.e. 2008-09 to 2012-13. The data consists of both financial as well as social performance indicators. The performance indicatorshave been determinedthrough an extensive literature review. Numerous studies have been using loan related variables for social performance measurement within which the depth of outreach is considered to be one of the significant factors in evaluating the operations of MFIs. The average loan $\operatorname{size}^{2}$ (ALS)is used to measure the depth whereas Number of Active Borrowers (NAB) and Gross loan portfolio (GLP) of measuring the outreach(Mosley \& Hulme, 1998; MacIntosh, De Janvry \& Sadoulet, 2005; Mersland \& Strøm, 2010; Wagenaar, 2012; Kar, 2013). The physical performance of the MFIs is determined by using a number of personnel and number of branches established. The financial performance is measured using the universally accepted criteria such as return on assets (ROA) and operational self-sustainability ${ }^{3}$ (OSS). The linkage tothetrade-offis analyzed through the financial performance which includes ROA, OSS and portfolio at risk (PAR 30 days) along with Operating Expense to Loan Portfolio (OETGLP). The ALS is found to be characterized by many researchers as one of the double bottom line criteria representing social performance and OSS as the measure for overall financial performance including sustainability(Copestake, 2007; Omri and Chkoundali, 2011; Bassem, 2012; Serrano-Cinca and Gutiérrez-Nieto, 2013; Louis, Seret and Baesens, 2013).

An overall industry analysis for the Indian MFI industry is done. The analysis has been extended by segregating the Indian MFIs into various categories i.e. legal status, age and outreach giving a discrete view of the industry. The categorization are explained in details in their respective section. An econometric analysis has been carried out for the second objective where two models are constructedon basis of two dependent variables i.e. ALS and OSS. Random effect panel regression is used with three dummy variables for the aforesaid mentioned MFI categories and with other relevant explanatory variables, which are normalized by natural logarithms. Hausman Test and basic panel regression properties do uphold both the models.

\section{Analysis:}

\section{Overall Industry}

The analysis begins with assessing the physical performance of all the Indian MFIs where decent growth is observed in assets as well as in a number of personnel and number of offices. In terms of social performance, the ALS shows a $7.37 \%$ growth, the GLP has $14.27 \%$ growth and the NAB has increased over $10.21 \%$. However, the financial performance shows a decline over the years that indicates the downturn in the financial sustainability of theindustry. The ROA has been declining, as so the OSS. This is well supported by increasing PAR30indicating deterioration the portfolio quality. Table 1 represents the above variables in an organized way. In the first section of theanalysis, a positive growth in the physical and social performance is seen which is impressive however it has no linkage with the financial performance of the MFIs in the industry. Moreover, the NAB growth is much lower than the GLP growth which also indicates that the loan amounts are creeping high. This can also be seen in the positive growth of the ALS. The PAR30 growth is higher due to the fact that the GLP disbursements are on the higher side. Further,the analysis is drawn-out by comparing ALS, ROA, OSS, and PAR30 of Indian MFIs to the World values for the year 2013. It is found that the ALS for the World stands at US\$ 194, ROA at 0.014, OSS at 1.106, and PAR30 at 0.026. The ALS is impressive for the Indian MFIs as they managed to keep it low. As for the other variables,no difference was observed with the global figures. 
Table 1: Performance Indicators

\begin{tabular}{|c|c|c|c|c|c|c|c|}
\hline Indicators & Variables & 2009 & 2010 & 2011 & 2012 & 2013 & $\begin{array}{c}5 \text { year } \\
\text { Growth }\end{array}$ \\
\hline \multirow{3}{*}{$\begin{array}{c}\text { Physical } \\
\text { Performance } \\
\text { (Total) }\end{array}$} & $\begin{array}{c}\text { Assets (in mll } \\
\$ \text { \$) }\end{array}$ & 2589.24 & 5126.19 & 5835.19 & 4646.73 & 4524.93 & 10.72 \\
\hline & $\begin{array}{l}\text { Personnel } \\
\text { (no.) }\end{array}$ & 64025 & 96187 & 113122 & 95291 & 77240 & 3.73 \\
\hline & $\begin{array}{c}\text { Offices } \\
\text { (no.) }\end{array}$ & 7253 & 10434 & 12690 & 11983 & 10681 & 9.55 \\
\hline \multirow[t]{3}{*}{$\begin{array}{l}\text { Outreach/Social } \\
\text { Performance }\end{array}$} & $\begin{array}{c}\text { ALS } \\
\text { (median) }\end{array}$ & 110 & 142 & 142 & 142 & 157 & 7.37 \\
\hline & $\begin{array}{c}\text { GLS (in mll } \\
\$ \text { ) }\end{array}$ & 2239.22 & 4615.94 & 5379.56 & 4313.91 & 4513.76 & 14.27 \\
\hline & $\begin{array}{l}\text { NAB ( in } \\
\text { mll) }\end{array}$ & 16.75 & 27.65 & 32.62 & 26.59 & 27.77 & 10.21 \\
\hline \multirow{3}{*}{$\begin{array}{c}\text { Financial } \\
\text { Performance } \\
\text { (Median) }\end{array}$} & ROA (\%) & 0.0189 & 0.0167 & 0.0136 & 0.009 & 0.012 & -- \\
\hline & OSS (\%) & 1.1132 & 1.1009 & 1.0953 & 1.071 & 1.087 & -- \\
\hline & PAR30 (\%) & 0.0037 & 0.005 & 0.0109 & 0.013 & 0.005 & -- \\
\hline
\end{tabular}

\section{Source: Computed}

Table 2 presents these variables below. The financial structure indicators depict the funding pattern of the MFIs. The Debt to Equity Ratio (DTE) shows a negative growth indicating that the MFIs are reducing debt and incorporating equity-oriented approach. This is also due to the fact that for financing MFIs the bankers in India do prefer a lower than 5:1 DE ratio as suggested by RBI.

\section{Table 2: Other indicators}

\begin{tabular}{|c|c|c|c|c|c|c|c|}
\hline Indicators & Variables & 2009 & 2010 & 2011 & 2012 & 2013 & 5 year Growth \\
\hline \multirow{2}{*}{$\begin{array}{l}\text { Financial } \\
\text { Structure }\end{array}$} & DE Ratio & 5.905 & 5.175 & 4.345 & 2.8 & 3.315 & --- \\
\hline & GLPTA (\%) & 0.813 & 0.827 & 0.839 & 0.857 & 0.839 & $-\cdots$ \\
\hline \multirow[t]{2}{*}{ Revenue } & FRTA (\%) & 0.211 & 0.203 & 0.239 & 0.219 & 0.206 & -- \\
\hline & $\begin{array}{c}\text { Profit margin } \\
(\%)\end{array}$ & 0.104 & 0.097 & 0.087 & 0.071 & 0.08 & -- \\
\hline \multirow[t]{3}{*}{ Efficiency } & OETGLP (\%) & 0.106 & 0.116 & 0.126 & 0.135 & 0.111 & --- \\
\hline & $\begin{array}{c}\text { Cost per loan } \\
\text { (\$) }\end{array}$ & 11.5 & 15 & 16 & 16 & 15 & 6.14 \\
\hline & LPS (median \$) & 227 & 217 & 221 & 208 & 256 & 2.04 \\
\hline
\end{tabular}

Source: Computed

With regard to the revenue indicators, the Financial Revenue to Total Assets (FRTA) shows a moderate growth. The profit margin has an unimpressive performance giving indications that the industry has not been in thegood show in terms of revenue generation. The efficiency indicators are also indifferent from the above indicators. The cost per loan administered to the clients shows a growth of $6.14 \%$ over the years indicating the rise of interest charges paid to the financiers on the borrowed amount. The loan per staff (LPS) which represents efficiency reveals a moderate growth. Although the physical and social performance is good in the Indian MFIs as compared to financial performance nevertheless the industry has no signs of atrade-off as the MFIs are trying their best to fulfill the commitments of double bottom line.

\section{Segregated Industry Analysis:}

There are numerous classifications in the MFIs that help in understanding its effects for generating the double bottom line commitments. These classifications are accepted worldwide for abetter understanding of the various factors that hold responsible for the operations of the MFIs. Few classifications are selected for the study which are explained with the help of important indicators. 


\section{a. Legal Status:}

To understand the impact of ownership on the operations, the MFIs are segregated as per their current legal status. In India, MFIs are classified ${ }^{4}$ into various categories, like NGOs, Section 8 companies (earlier Section 25 companies), Cooperative Societies, Trusts, Non-banking Finance Companies (NBFCs) and some small local area rural banks. The segregation is done into two distinct categories. The first one is less regulated one which includes the first of the five categories. This is grouped by NGO category. The Section 8 , Cooperative societies, and NBFC MFIs and others are placed under thenon-NGO category. Table 3 represents the performance (physical, social, and financial) of the MFIs. To begin with, it can be observed that the physical performance of the non-NGO MFIs is on the better side as compared to the NGO MFIs. Although the ALS is on the lower side in NGO MFIs, however the other aspects of outreach such as GLS and NAB are higher in non-NGO MFIs. This indicates that NGO MFIs are better in maintaining the depth of outreach whereas the non-NGO MFIs are better in maintaining the breadth. The financial performance is not very encouraging for both the forms of MFIs. The returns are positive for both the forms of MFIs however it has a decreasing trend in non-NGO MFIs. In spite of having a better physical performance, the non-NGO MFIs are yet to perform in a sustainable way financially as compared to NGO MFIs. Also, a higherlevel of PAR30 in recent years for the non-NGO MFIs in comparison to the NGO MFIs is a cause of worry for the former giving anindication of possible NPAs. Moving on with the analysis of the other indicators represented in Table 3. The growth of gross loan portfolio to total assets is higher in non-NGO MFIs indicating higher conversion of total resources into loan assets. While determining the efficiency it was found that the operating expenses to loan portfolio are decreasing in non-NGO MFIs. The analysis also indicates that the non-NGO MFIs are better in terms of social performance than the NGO MFIs. Nevertheless, they are lagging behind NGO MFIs in sustaining their financial performance even though both non-NGO and NGO MFIs are financially sustainable. Sustainability, however, has deteriorated over the years.

Table 3: Performance Indicators as per the classifications

\begin{tabular}{|c|c|c|c|c|c|c|c|c|c|c|c|}
\hline \multirow{2}{*}{\multicolumn{2}{|c|}{ Categories }} & \multirow{2}{*}{$\begin{array}{l}\text { Indicators } \\
\text { Variables }\end{array}$} & \multicolumn{2}{|c|}{$\begin{array}{c}\text { Physical } \\
\text { Performance }\end{array}$} & \multicolumn{3}{|c|}{ Outreach/Social Performance } & \multicolumn{4}{|c|}{ Financial Performance (Median) } \\
\hline & & & $\begin{array}{l}\text { Personnel } \\
\text { (no.) }\end{array}$ & $\begin{array}{c}\text { Offices } \\
\text { (no.) }\end{array}$ & ALS(median) & $\begin{array}{c}\text { Total } \\
\text { GLP (in } \\
\text { mll \$) }\end{array}$ & $\begin{array}{c}\text { Total } \\
\text { NAB ( } \\
\text { in mll) }\end{array}$ & $\begin{array}{c}\text { ROA } \\
(\%)\end{array}$ & $\begin{array}{l}\text { OSS } \\
(\%)\end{array}$ & $\begin{array}{c}\text { PAR30 } \\
(\%)\end{array}$ & $\begin{array}{c}\text { OETGLP } \\
(\%)\end{array}$ \\
\hline \multirow{5}{*}{$\begin{array}{l}\text { Legal } \\
\text { Status }\end{array}$} & \multirow{2}{*}{$\begin{array}{l}\text { Non- } \\
\text { NGO }\end{array}$} & $2009(58)$ & 50211 & 6050 & 124 & 1955.36 & 14.07 & 0.0186 & 1.1349 & 0.0033 & 0.1226 \\
\hline & & $2013(63)$ & 65639 & 9758 & 165 & 3945.06 & 24.13 & 0.0107 & 1.086 & 0.0058 & 0.1116 \\
\hline & \multirow{2}{*}{ NGO } & $2009(39)$ & 13780 & 1202 & 103 & 283.04 & 26.64 & 0.0284 & 1.1067 & 0.0041 & 0.0986 \\
\hline & & $2013(29)$ & 11558 & 911 & 147 & 568.27 & 36.27 & 0.0208 & 1.0919 & 0.0037 & 0.1007 \\
\hline & \multicolumn{2}{|c|}{5 year Growth } & -2.08 & -4.27 & 7.78 & 18.41 & 4.58 & --- & -- & --- & --- \\
\hline \multirow{4}{*}{ Age } & \multirow{2}{*}{ Mature } & $2009(52)$ & 46333 & 4893 & 121 & 1746.14 & 12.28 & 0.02615 & 1.1417 & 0.0039 & 0.1051 \\
\hline & & $2013(47)$ & 63214 & 8583 & 163 & 3853.64 & 23.44 & 0.0105 & 1.07345 & 0.008 & 0.1011 \\
\hline & New & 2013 (47) & 14026 & 2098 & 156 & 660.12 & 4.33 & 0.01475 & 1.0974 & 0.0027 & 0.114 \\
\hline & \multicolumn{2}{|c|}{5 year Growth } & -5.02 & 1.3 & 9.22 & 7.26 & 0.56 & -- & -- & -- & $-\cdots$ \\
\hline \multirow{6}{*}{$\begin{array}{l}\text { Outreack } \\
\text { Size }\end{array}$} & \multirow{2}{*}{ Large } & $2009(53)$ & 61838 & 6922 & 113 & 2174.4 & 16.41 & 0.0236 & 1.1724 & 0.0033 & 0.1078 \\
\hline & & $2013(59)$ & 75281 & 10391 & 154 & 4441.48 & 27.38 & 0.0111 & 1.086 & 0.00535 & 0.1043 \\
\hline & \multicolumn{2}{|c|}{5 year Growth } & 3.95 & 9.95 & 5.97 & 14.47 & 10.33 & --- & -- & -- & --- \\
\hline & \multirow{2}{*}{ Small } & $2009(37)$ & 2129 & 315 & 106 & 51.77 & 0.33 & 0.0168 & 1.0422 & 0.0057 & 0.106 \\
\hline & & $2013(34)$ & 1959 & 290 & 165.5 & 72.28 & 0.39 & 0.013 & 1.0879 & 0.0049 & 0.1216 \\
\hline & \multicolumn{2}{|c|}{5 year Growth } & -2.79 & 0.29 & 9.66 & 7.37 & 3.19 & --- & -- & --- & --- \\
\hline
\end{tabular}


The analysis further shows that the physical growth of the non-NGO MFIs is much higher than the NGO MFIs however they lack in transforming their operations to break even let alone gaining profits. Further, many NGO MFIs transformed themselves into NBFCs lately which is another element of non-NGO MFIs. This might affect the results between the two forms of MFIs. The notion that non-NGO MFIs are much more commercially oriented does not standsolidly in the analysis. Moreover, these non-NGO MFIs are also categorized in theforprofit category as the NGO MFIs are in not for profit category. Thus even if the NGO MFIs have a low growth in social performance, physical growth and another aspect of operations as compared to non-NGO MFIs yet they have managed to attain financial sustainability over the years maintaining confidence in the industry for the investors. Nevertheless, the non-NGO MFIs are also operating in a closed circuit with better performance in near future.

\section{b. Age :}

To apprehend the effect of time in the operations, the MFIs are classified on the basis of their age. Age categories consist of two segments one for new and other for mature. The new category consists of MFIs which are operating from 1 to 8 years and the mature category consists of MFIs which are operating beyond 8 years. Table 3 represents the performance (physical, social, and financial) of the MFIs as per the classification. It can beseen that the matured MFIs are better in physical as well as social performance than the new MFIs. All of the variables except ALS have a high growth in matured MFIs. Although the ALS growth is higher in the new MFIs the lower average amount of ALS in matured MFIs is preferable for better depth alongside better breadth. Even with such an impressive performance in other aspects, the financial performance of the matured MFIs shows a downhill trend. In a lower scale, the same is observed in new MFIs too. Further, the scale of operations is higher in matured MFIs in comparison to new MFIs thus the PAR30 is also higher indicating exposure to higher risk in the form of NPAs. The operating expenditure in the new MFIs is slightly higher than the old MFIs. This is mainly due to the initial stage of their operation. With due course of time hopefully, they will be able to rationalize their expenditure in a better way. The analysis gives us an indication that time influences the operations of the MFIs. As the MFIs become experienced they go for less risky clientele and possibly trade-off. However,thestudydoes not give any concrete evidence of trade-off in either of the new or mature MFIs. Although there are other indicators that fluctuate with time.

\section{c. Outreach Classification:}

The last segment in performance analysis relates to classification on the basis of outreach which consists of Large MFIs and Small MFIs in terms ofnumber of borrowers i.e. breadth. Large MFIs indicates number of borrowers beyond 30,000 and small MFIs indicate thenumber of borrowers till 30,000.From the above table, is is observed that the physical and social performance of large MFIs is better than the small MFIs indicating that higher breadth of outreach adheres to better performance. The ALS also has a decreasing trend in the large MFIs indicating better depth in its outreach than the Small MFIs. However, the financial performance follows the same trend like previous analyses with shrinking tendency. Unlike the large MFIs, the Small MFIs are better in financial performance with anupward trend and better returns. Furthermore, the PAR30 is also high in large MFIs as compared to the Small MFIs indicating the accumulated NPAs. The operating expenditure efficiency also shows a better trend in Small MFIs. Thus the financial performance of the small MFIs is better in comparison to Large MFIs yet they are low in social performance.

The above-segregated analysis does not provide any solid indications of trade-off. It is found that NGO, new and large MFIs were better in terms of attaining social objective by reaching the poor with small loan i.e. low ALS. Similarly, NGO, new and small MFIs were found to be better in achieving sustainability. On the whole both NGO and new categories of MFIs score over Non-NGO and mature MFIs.

\section{Econometric Analysis:}

The analysis carried out in the last section gives us a view of the double bottom line commitments from various multi-facet angles. However, without exploring the associative properties among the variables included in it the question of thedouble bottom line remains unresolved. This prompts the analysis being carried out by incorporating econometric modeling to ascertain the relationship if any between the explained and explanatory variables. A panel data regression model is used based on the data available on the Indian MFIs for the period of the study. For one aspect of double bottom line i.e. social performance, average loan size (ALS) is used as thedependent variable. The other model covers the other facet i.e. the overall financial performance by taking operational self-sustainability (OSS) as thedependent variable. The rationale behind this is that it would give a 
better view from both social as well as financial perspective. The description of the variables is shown in Table 4.

The relationship status of the variables is mostly derived from the literature available in the context and in some cases, they are assumed. There are various conflicting as well as regular associations among them in different studies. The literature does not provide any concrete relationship of outreach depth with sustainability, which is also assumed in the study. Since the outreach scale in terms of gross loan portfolio indicates the most important business activity of MFIs, a positive association is expected with the loan size as well with sustainability. This is driven by the very fact that larger loan size reduces operating expenditure to a great extent which again positively impacts sustainability. The physical performance captured through number of personnel is likely to have either type relationship with the dependent variables. Further better sustainability attributable to reduced expenditure possibly holds a positive association with large loan size. Similarly, profitability indicated through return on asset is also assumed to have apositive association with both loan size and sustainability. The reason behind this is that a large loan size as explained earlier reflects high operational self-sustainability which is again mirrored in the returns. The efficiency indicator is supposed to have a negative association with average loan size as well as with sustainability. The same is observed with risk indicator as a lower portfolio at risk is linked to large loan size and better sustainability. Keeping in view with the contradictory findings in the literature all the dummy indicators are expected to have either type of relationship with the dependent variables.

Table 4: Variables and their definition used for econometric analysis

\begin{tabular}{|c|c|c|c|c|}
\hline Indicator & Variables & Definitions & $\begin{array}{l}\text { Expected } \\
\text { Relationshi } \\
\text { p with ALS }\end{array}$ & $\begin{array}{l}\text { Expected } \\
\text { Relationshi } \\
\text { p with OSS }\end{array}$ \\
\hline Outreach Depth & ALS & $\begin{array}{l}\text { Adjusted Gross Loan Portfolio/Adjusted } \\
\text { Number of Active Borrowers }\end{array}$ & ------- & $+/-$ \\
\hline Outreach Scale & GLP & $\begin{array}{l}\text { Gross Loan Portfolio, adjusted for } \\
\text { standardized write-offs }\end{array}$ & + & + \\
\hline $\begin{array}{l}\text { Physical } \\
\text { Performance }\end{array}$ & PERSONNEL & Total number of Personnel Employed & $+/-$ & $+/-$ \\
\hline Sustainability & OSS & $\begin{array}{l}\text { Operational Self-Sufficiency. Financial } \\
\text { Revenue / (Financial Expense + Impairment } \\
\text { Losses on Loans }+ \text { Operating Expense) }\end{array}$ & $+/-$ & -------- \\
\hline Profitability & ROA & $\begin{array}{l}\text { Net Operating Income after Taxes / Average } \\
\text { Total Assets }\end{array}$ & + & + \\
\hline Efficiency & OETGLP & Operating Expense to Gross Loan Portfolio & - & - \\
\hline Risk & PAR30 & $\begin{array}{l}\text { Outstanding balance, portfolio overdue }>30 \\
\text { days }+ \text { renegotiated portfolio /Gross Loan } \\
\text { Portfolio }\end{array}$ & - & - \\
\hline Legal Status & DUMMY & $\begin{array}{l}\text { Dummy variable } 1 \text { for NGO MFIs and } 0 \text { for } \\
\text { non-NGO MFIs }\end{array}$ & $+/-$ & $+/-$ \\
\hline Age & DUMMY & $\begin{array}{l}\text { Dummy variable } 1 \text { for Mature MFIs i.e. age } \\
>\text { 8years and } 0 \text { for New MFIs i.e. age } \leq \\
\text { 8years }\end{array}$ & $+/-$ & $+/-$ \\
\hline Outreach Size & DUMMY & $\begin{array}{l}\text { Dummy variable } 1 \text { for Large MFIs i.e. }> \\
30000 \text { borrowers and } 0 \text { for Small MFIs i.e. } \leq \\
30000 \text { borrowers }\end{array}$ & $+/-$ & $+/-$ \\
\hline
\end{tabular}

Source: Compiled

The models used for the analysis are as follows:

$$
\begin{aligned}
& A L S_{k}=\beta_{0}+\beta_{1} \text { OSS }_{k}+\beta_{2} \text { OETGLP }_{k}+\beta_{3} \text { Personnel }_{k}+\beta_{4} \text { ROA }_{k}+\beta_{5} \text { PAR30 }_{k}+\beta_{6} \text { GLP }_{k}+ \\
& \beta_{7} D_{1} \text { Age }_{k}+\beta_{8} D_{2} \text { LegalStatus }_{k}+\beta_{9} D_{3} \text { OutreachSize }_{k}+e_{k} \\
& \text { OSS }_{k}=\beta_{0}+\beta_{1} A L S_{k}+\beta_{2} \text { OETGLP }_{k}+\beta_{3} \text { Personnel }_{k}+\beta_{4} \text { ROA }_{k}+\beta_{5} \text { PAR3O }_{k}+\beta_{6} \text { GLP }_{k}+ \\
& \beta_{7} D_{1} \text { Age }_{k}+\beta_{8} D_{2} \text { LegalStatus }_{k}+\beta_{9} D_{3} \text { OutreachSize }_{k}+e_{k}
\end{aligned}
$$


Out of all the independent variables integrated into the model, four variables have asignificant relationship with the loan size (Table 5). The gross loan portfolio has a significant positive relationship between the average loan size i.e. an increase in loan portfolio also increases the loan size. In conformity to the expectation efficiency shows a significant negative association with the loan size meaning a swell in the efficiency variable i.e. inefficiency shrinks the average loan size. Further,number of personnel has a significant positive association with ALS which gives an idea that when thenumber of personnel increases it also spikes an increase in loan size. For the outreach size dummy, large MFIs have lower ALS than small MFIs. Although the low $R^{2}$ value of ALS model indicates not as much of strength however it is significant and these four significant variables to some extent explain the relationships with average loan size. This is also observed in the segregated industry analysis where large size Indian MFIs is showing their commitment to double bottom line in terms of small loan size.

\section{Table 5: Panel Regression Results}

\begin{tabular}{|c|c|c|c|c|c|c|}
\hline \multirow[t]{2}{*}{ Variable } & \multicolumn{3}{|c|}{ ALS MODEL } & \multicolumn{3}{|c|}{ OSS MODEL } \\
\hline & Coefficient & t-Statistic & Prob. & Coefficient & t-Statistic & Prob. \\
\hline ALS & ---- & ---- & --- & 0.015 & 0.936 & 0.350 \\
\hline GLP & $0.173^{*}$ & 6.460 & 0.000 & -0.009 & -0.822 & 0.412 \\
\hline OETGLP & -0.154 & -2.706 & 0.007 & 0.005 & 0.235 & 0.815 \\
\hline OSS & 0.103 & 0.934 & 0.351 & ---- & ---- & ---- \\
\hline PAR30 & -0.030 & -1.577 & 0.115 & $-0.026^{*}$ & -3.573 & 0.000 \\
\hline PER & $0.194^{*}$ & 5.208 & 0.000 & -0.016 & -1.115 & 0.265 \\
\hline ROA & 0.002 & 0.062 & 0.951 & $-0.057^{*}$ & -5.991 & 0.000 \\
\hline DAGE & -0.126 & -1.237 & 0.217 & -0.017 & -0.434 & 0.665 \\
\hline DLEGAL & 0.170 & 1.572 & 0.117 & 0.056 & 1.356 & 0.176 \\
\hline DOUTSIZE & $-0.786^{*}$ & -5.941 & 0.000 & $0.086^{* *}$ & 1.647 & 0.100 \\
\hline $\mathbf{C}$ & $1.144^{*}$ & 3.523 & 0.001 & -0.114 & -0.907 & 0.365 \\
\hline R-squared & 0.291 DW Stat & 1.972 & R-sql & 0.134 & DW Stat & 1.680 \\
\hline F-statistic & $25.124^{*}$ & & F-sta & 9.495 & & \\
\hline $\begin{array}{l}\operatorname{Prob}(\mathbf{F}- \\
\text { statistic) }\end{array}$ & $\mathbf{0}$ & & Prob & tatisti & & \\
\hline
\end{tabular}

Source: Computed by the author

NB: * and ** denote variables significant at 1 per cent and 10 per cent respectively

The second model based on operational self-sustainability (OSS) gives anindication of association for three variables. As expected the risk indicator has a significant negative association with sustainability where an increase in it signifies high non-performing assets which are reflected through low operational sustainability. However, a significant negative relationship of return with the operational self-sustainability is seen which is not as per normal expectation. Thus, the significant relationship with size explains that large size MFIs are capable enough to manage their cost and remain operationally viable thus showing their commitment to double bottom line in terms of sustainability.

\section{Observations:}

The microfinance crusade started with a single philosophy of serving the poor inorder to develop the poverty driven society by accomplishing an all-round socio-economic development. However, with time and modern effect of business environment, it has changed into a diverse platform all together where mere social performance does not help to meet its needs. This led to the transformation of many MFIs into aregulated sphere and the drying-up of donor funding subsequently pushed the MFIs to look for commercial funding. However, many players emerged in this process where some had a profit motive that brought in adverse outcomes in the operations of the MFIs. Today along with social performance the MFIs also need to be financially sustainable in order to survive its endless demand for funds to develop its services. The idea of double bottom line generates this concept as it would create an optimum situation for both the poor and the MFIs. But there areevidence that talks about trade-off where MFIs incline to attain profitability rather than social performance.

The recent changes in MFIs sector in India, particularly during the post-Andhra Pradesh crisis period has renewed interest among the policy makers to reorient their approach to this sector. The recognition of a section of MFIs as NBFC-MFIs by RBI and subsequent implementation of Malegam committee recommendations are 
clear indications of a professional approach to this sector. Subsequently, the sole social objective vociferously advocated by Prof. Yunus has been tagged with financial sustainability. This has ultimately made MFIs as profit seeking but socially responsible institutions. Though sounds perfect the tendency among the profit seekers to digress from the real mission is also visible in some parts of the world. The study reveals a modest commitment of MFIs, particularly from large MFIs to both the objectives is a matter of relief. However, looking at the recent emphasis of MFIs on commercial funding like private equity, securitisation and other debt sources the future cannot be fully assured. The need of the hour is to bring the Microfinance Bill, which is pending for quite some time in the Parliament into immediate effect and ensuring greater accountability of the MFIs particularly the NGOs, which are presently not adequately covered under the regulatory framework. Furthermore, the large MFIs in India need to be closely monitored since they are pursued by other smaller MFIs. Any trade-off in double bottom line by the former MFIs could bring negative ramifications for the industry as a whole.

\section{NOTES:}

1. www.mixmarket.org is a web-based platform that maintains financial as well as social information of major microfinance institutions located throughout the World. It is anon-profitorganization that acts as a database for the funders, investors and other interested parties in the field of microfinance. Its head office is located in Washington DC, and the regional offices are located in Peru, Morocco, and India. It has been founded by the Consultative Group to Assist the Poor (CGAP). Many of the research studies are based on its data base.

2. Schreiner (2002) identified average loan size (ALS) as an important aspect of depth of outreach. As a uniform benchmark, it is believed that if ALS is low the outreach is greater as poorer can afford the loans (Mersland and Strøm, 2010; Hermes, Lensink and Meesters, 2011). This makes it be an important indicator to measure the penetration of the MFIs. Many researchers have used ALS as a vital indicator for their study (Mosley and Hulme, 1998; Woller, Dunford and Woodworth, 1999; Christen, 2001; Olivaries-Polanco, 2005; Copestake, 2007; Hermes, Lensink and Meesters, 2011; Roberts, 2013; Sheremenko, Escalante and Florkowski, 2012; Quayes, 2012; Kar, 2013; Serrano-Cinca and Gutiérrez-Nieto, 2013).

3. The sustainability of MFIs is captured by operating self-sufficiency (OSS) indicating whether the MFIs are able to generate adequate returns to cover their total costs i.e. operational expenses, loan loss provisions, and financial costs. It is favored over FSS because OSS is quantifiable measurement, unlike FSS which has qualitative information.

4. Legal status classification consists of two group viz. NGO and Non-NGO MFIs. The NGO MFIs consists of organizations set up under Societies Registration Act, 1860 as Registered Society, Public Trusts, aPrivatetrust under the Indian Trusts Act of 1882, and Non-profit organization under Section 8 of Companies Act 2013. The Non-NGO group primarily consists of NBFCs, Rural Bank regulated by RBI and Cooperatives, MACS, credit unions under the regulation of State Government.

\section{References:}

[1] Adams, D. W., \& Von Pischke, J. (1992). Microenterprise credit programs: Déjà vu. World development, 20(10), 1463-1470.

[2] Ashta, A., \& Hudon, M. (2009). To whom should we be fair? Ethical issues in balancing stakeholder interests from Banco Compartamos case study.CEB Working Paper No. 09/036.Retrieved from http://dx.doi.org/10.2139/ssrn.1470643

[3] Augsburg, B., \& Fouillet, C. (2010). Profit Empowerment: The Microfinance Institutions Mission Drift. Perspectives on Global Development and Technology, 9(3-4), 3-4.

[4] Ayayi, A. G., \& Sene, M. (2010). What drives microfinance institution's financial sustainability.The Journal of Developing Areas, 44(1), 303-324.

[5] Barzelay, J. (2008). Bancosol: Mission Drift in Microfinance Institutions.Retrieved fromCouncil on Hemispheric Affairs (COHA) website http://www.coha.org/bancosol-mission-drift-in-microfinanceinstitutions/

[6] Bassem, B. S. (2012). Social and financial performance of microfinance institutions: Is there a tradeoff? Journal of Economics and International Finance, 4(4), 92-100.

[7] Bédécarrats, F., Baur, S., \& Lapenu, C. (2012). Combining social and financial performance: A paradox? Enterprise Development and Microfinance, 23(3), 241-258.

[8] Christen, R., \& Drake, D. (2001). Commercialization of Microfinance, Microenterprise Best Practices: Working Paper. Retrieved from: http://mfbbva. org/uploads/tx_bbvagbmicrof/Commercialization_of_Microfinance.pdf.

[9] Christen, R. P. (2001). Commercialization and mission drift. CGAP Occasional Paper(5).Retrieved from http://www.cgap.org/sites/default/files/CGAP-Occasional-Paper-Commercialization-and-Mission-Drift-The- 
Transformation-of-Microfinance-in-Latin-America-Jan-2001.pdf.

[10] Coleman, R. W. (2008). As the microfinance movement grows it encounters new challenges and opportunities. In International Trade and Finance Association Conference Papers (p. 34). Bepress. Retrieved from http://services.bepress.com/cgi/viewcontent.cgi?article=1139\&context=itfa

[11] Copestake, J. (2007). Mainstreaming microfinance: social performance management or mission drift? World development, 35(10), 1721-1738.

[12] Cull, R., Demirgüç-Kunt, A., \& Morduch, J. (2007). Financial Performance and Outreach: A Global Analysis of Leading Microbanks. The Economic Journal, 117(517), F107-F133.doi: 10.2307/4625477

[13] Dowla, A., \&Barua, D. (2006).The poor always pay back: The Grameen II story: Kumarian Press.

[14] Frank, C., Lynch, E., \& Schneider-Moretto, L. (2008).Stemming the tide of mission drift: microfinance transformations and the double bottom line. Washington, DC: Women's World Banking. Retrieved from http://www.microfinancegateway.org/library/stemming-tide-mission-drift-microfinancetransformations-and-double-bottom-line

[15] Ghosh, S., \& Van Tassel, E. (2008). A model of mission drift in microfinance institutions. Department of Economics, Florida Atlantic University, December. Retrieved from http://www.microfinancegateway.org/sites/default/files/mfg-en-paper-a-model-of-mission-drift-in-microfinanceinstitutions-dec-2008_0.pdf

[16] Hermes, N., \& Lensink, R. (2007). The empirics of microfinance: what do we know? The Economic Journal, 117(517), F1-F10.

[17] Hermes, N., Lensink, R., \& Meesters, A. (2011).Outreach and efficiency of microfinance institutions. World development, 39(6), 938-948.

[18] Hollis, A., \& Sweetman, A. (1996). THE EVOLUTION OF AMICROCREDIT INSTITUTION: THE IRISH LOAN FUNDS, 1720-1920 (No. ecpap-96-01).

[19] Hulme, D., \&Maitrot, M. (2014). Has Microfinance Lost Its Moral Compass? Economic \& Political Weekly, 49(48), 77.

[20] Kabeer, N. (2005). Is microfinance a magic bullet for women's empowerment? Analysis of Findings from South Asia. Economic and Political Weekly, 4709-4718.

[21] Kai, H. (2009). Competition and wide outreach of Microfinance Institutions". Economics Bulletin, 29(4), 2628-2639.

[22] Kar, A. K. (2013). Mission drift in microfinance: are the concerns really worrying? Recent crosscountry results. International Review of Applied Economics, 27(1), 44-60.

[23] Louis, P., Seret, A., \& Baesens, B. (2013). Financial efficiency and social impact of microfinance institutions using self-organizing maps. World Development, 46, 197-210.

[24] McIntosh, C., Janvry, A., \& Sadoulet, E. (2005). How Rising Competition Among Microfinance Institutions Affects Incumbent Lenders*. The Economic Journal, 115(506), 987-1004.

[25] Mersland, R., \& Strøm, R. Ø. (2007). Microbanks: Ownership, performance and social tradeoffs-a global analysis: University Library of Munich, Germany. Retrieved from http://mpra.ub.unimuenchen.de/2063/

[26] Mersland, R., \& Strøm, R. Ø. (2010).Microfinance mission drift? World development, 38(1), 28-36.

[27] Morduch, J. (2000). The microfinance schism. World development, 28(4), 617-629.

[28] Mosley, P., \& Hulme, D. (1998). Microenterprise finance: is there a conflict between growth and poverty alleviation? World development, 26(5), 783-790.

[29] Nair, T. (2010). Commercial microfinance and social responsibility: a critique. Economic \& Political Weekly, 45(31),32- 37.

[30] Olivares-Polanco, F. (2005). Commercializing microfinance and deepening outreach? Empirical evidence from Latin America. Journal of Microfinance/ESR Review, 7(2), 47-69.

[31] Quayes, S. (2012). Depth of outreach and financial sustainability of microfinance institutions. Applied Economics, 44(26), 3421-3433.

[32] Rhyne, E. (1998). The yin and yang of microfinance: Reaching the poor and sustainability. MicroBanking Bulletin, 2(1), 6-8.

[33] Roberts, P. W. (2013). The profit orientation of microfinance institutions and effective interest rates. World Development, 41, 120-131.http://dx.doi.org/10.1016/j.worlddev.2012.05.022

[34] Rosengard, J. K. (2004). Banking on social entrepreneurship: the commercialization of microfinance. Mondes en développement (2), 25-36.

[35] Salim, M. M. (2013). Revealed Objective Functions of Microfinance Institutions: Evidence from Bangladesh. Journal of Development Economics, 104, 34-55.

[36] Schreiner, M. (2002). Aspects of outreach: A framework for discussion of the social benefits of microfinance. Journal of International Development, 14(5), 591-603.

[37] Serrano-Cinca, C., \& Gutiérrez-Nieto, B. (2014). Microfinance, the long tail and mission drift. International Business Review, 23(1), 181-194.

[38] Sheremenko, G., Escalante, C. L., \& Florkowski, W. J. (2012).The Universality of Microfinance Operations Model in Eastern Europe and Central Asia: Financial Sustainability vs. Poverty Outreach. Paper presented at the 2012 Annual Meeting, August 12-14, 2012, Seattle, Washington.

[39] Shylendra, H. (2006). Microfinance institutions in Andhra Pradesh: crisis and diagnosis. Economic and Political Weekly, 1959-1963.

[40] Sriram, M. S. (2010). Commercialisation of Microfinance in India: A Discussion on the Emperor's Apparel: Indian Institute of Management. Retrieved from 
http://indiamicrofinance.com/files/2010/04/IIM-article.pdf

[41] Tchakoute-Tchuigoua, H. (2010). Is there a difference in performance by the legal status of microfinance institutions? The Quarterly Review of Economics and Finance, 50(4), 436-442.

[42] Wagenaar, K. (2012). Institutional transformation and mission drift in microfinance. Retrieved from http://www.unamur.be/en/eco/eeco/cred/papers/economics-of-non-profits/SP3_Wagenaar_UCamb.pdf

[43] Woller, G. (2007). Trade-offs between social and financial performance. Journal of Microfinance/ESR Review, 9(2), 14-19.

[44] Woller, G. M., Dunford, C., \& Woodworth, W. (1999).Where to microfinance. International Journal of Economic Development, 1(1), 29-64.

[45] Zerai, B., \& Rani, L. (2012). Is there a tradeoff between outreach and sustainability of micro finance institutions? evidence from Indian microfinance institutions (MFIs). Research Journal of Finance and Accounting, 2(11), 32-41. 